\title{
Intervention gentrification and everyday socio-economic transactions in intervention societies
}

DOI:

10.1080/13698249.2018.1466089

\section{Document Version}

Accepted author manuscript

Link to publication record in Manchester Research Explorer

\section{Citation for published version (APA):}

Thomas, J., \& Vogel, B. (2018). Intervention gentrification and everyday socio-economic transactions in intervention societies. Civil Wars. https://doi.org/10.1080/13698249.2018.1466089

\section{Published in:}

Civil Wars

\section{Citing this paper}

Please note that where the full-text provided on Manchester Research Explorer is the Author Accepted Manuscript or Proof version this may differ from the final Published version. If citing, it is advised that you check and use the publisher's definitive version.

\section{General rights}

Copyright and moral rights for the publications made accessible in the Research Explorer are retained by the authors and/or other copyright owners and it is a condition of accessing publications that users recognise and abide by the legal requirements associated with these rights.

\section{Takedown policy}

If you believe that this document breaches copyright please refer to the University of Manchester's Takedown Procedures [http://man.ac.uk/04Y6Bo] or contact uml.scholarlycommunications@manchester.ac.uk providing relevant details, so we can investigate your claim.

\section{OPEN ACCESS}




\title{
Gentrification and everyday socio-economic transactions in intervention societies
}

\author{
By Joely Thomas and Birte Vogel, University of Manchester
}

\begin{abstract}
This article calls for a focus on the economic everyday of intervention societies. It opens the debate by demonstrating the effects of intervention gentrification and sketching out different forms of local-intervener interactions. We argue that the majority of economic impacts are localised and connected to immediate geographic proximity and thus require a qualitative methodological approach. Further, many of these implications are of a socio-economic rather than purely economic nature, or only translate into economic changes over time. To demonstrate this, the article explores the socio-economic impact of everyday interactions and (non-)material transactions between local and international residents in the neighbourhood of Jabal al-Weibdeh, Amman. Given Jordan's location amidst conflict settings such as IsraelPalestine, Iraq and Syria, and its high refugee population, many international and regional non-governmental organisations focusing on humanitarianism and development, base themselves in Amman. Currently, the international community has no mechanisms in place to mitigate socio-economic effects of their presence possibly creating social conflict or at least economic precarity for some. It is therefore important to consider the economic effects of intervention societies and intervention gentrification in more far-reaching economic and social studies.
\end{abstract}

Keywords: intervention gentrification, Amman, spatial economics, interventions

At first glance, Jabal al-Weibdeh, a middle class ${ }^{1}$ neighbourhood of Jordan's capital Amman, is exemplary of the claim that international staff in the peacebuilding and humanitarian sectors group together. Ammanis tend not to be surprised when international staff ${ }^{2}$ state Weibdeh as their home address, as (mainly Western) humanitarian-, aid- and development workers, diplomats and international students choose to live in the area known for its cultural richness, architectural heritage and vibrant arts scene. This ties in with the critical observation that interveners have a tendency to retreat from local populations - spatially and culturally rather than engaging with the 'everyday' of the societies they are living in (Eyben 2011, Verma 2011). At the same time, it is widely recognised that international staff are not independent of the societies in which they live (Goetze and de Guevara 2012) but that an international presence affects the lives of those they share a space with, and form what is often referred to as an 'intervention society' ${ }^{3}$. This article argues that the social interactions that occur between interveners and locals are an integral part of economic transactions in the intervention society but that they have unintended socio-economic consequences; both deserve further analysis for which this article provides a conceptual frame and empirical evidence. 
A focus on the economic everyday of intervention societies is still largely absent from the literature. It is important, however, as many of economic impacts are connected to immediate geographic proximity. Despite the influx of foreign capital, larger economic changes usually do not occur as a result of an international humanitarian presence 4 (Rolandsen 2015, p.354, also Mvukiyehe 2018), and economic changes that can be detected are at large unsustainable beyond the end of the intervention period (see also Carnahan et al 2006; Beber et al, 2016). For instance, in a study on the impact of United Nations (UN) peacekeeping operations on economic growth in a set of 39 conflict-afflicted countries, Ernst et al (2014) find that an international presence does not increase the growth rate of gross domestic product (GDP) but the level of GDP per capita. ${ }^{5}$ Researchers have recently addressed both the positive and negative effects of economic interactions between the international community and host populations by focusing on international peacekeepers (Jennings 2015, Oldenburg 2015; Jennings and Boas 2015, Aning and Edu-Afful 2013). This research focuses on groups that are directly linked to the peacekeeping economy such as service workers (maids, security guards and sex workers) and the transfer of economic capital from foreign consumers to local vendors. Findings point to the unequal power dynamics between (economic) actors.

Less examined are the socio-economic interactions that take place between interveners and locals that provide a range of other opportunities across a wider spectrum of actors. While youth is often identified as looking to access the interveners' community for a "mobile and modern" lifestyle (Jennings and Boas 2015, p.292), current research tends to overlook other groups that may seek not only economic capital but beneficial social relations - or what is called wasta in the Middle Eastern context. ${ }^{6}$ This focus is partly attributable to the fact that extensive research on intervention societies is carried out in sub-Saharan African countries affected by violent conflict and higher levels of risk for international staff (see Autesserre 2014, Smirl 2015) or countries particularly engulfed in conflict and securitization processes, such as Iraq and Afghanistan (Chandrasekaran 2006). Furthermore, places studied so far tend to be low- or middle-income countries, where the income gap between the majority of the host population and well-paid international employees is much wider. This article tries to fill this research gap by focusing on the neighbourhood of Weibdeh. Jordan is classified as an upper middle-income country, ${ }^{7}$ such as Brazil, Turkey or Serbia, and humanitarians usually live alongside local residents rather than in guarded compounds.

In Weibdeh, we find that social networks bring long- and short-term benefits to several members of the intervention society. Analysing their transactions helps us to extend our 
understanding of intervention economies beyond the economic alone. By doing so, intervener-local relations are complicated and spatial boundaries blurred. The important role of social networks in intervention societies is stressed, while the dexterity of locals in using such 'currency' to better their situations mitigates the local-intervener power dynamics. In short, local neighbours perceive the international presence as beneficial as it provides them with opportunities for language learning, the preservation of the neighbourhood's cultural scene, and the consolidation of many residents' middle class status, while youth makes use of the social freedoms granted to internationals to challenge orthodox societal norms. Interveners, meanwhile, are able to create a 'home away from home', with behaviours permitted and social opportunities available that are less so in other parts of the city, a sense of security, and interactions with local residents that further provide them with access to knowledge and language skills that facilitate their experience in the country. We can, however, also identify processes of what we term intervention gentrification; a process of economic, cultural, social and infrastructural changes that result from interactions within the intervention society. They favour the dominant classes and displace the low-income segment of populations. Thus, intervention gentrification symbolises how broader processes of neoliberalisation are replicated in the local through the presence of humanitarian staff.

\section{Methodology and Categories of Analysis}

This article offers thick empirical descriptions and combines it with theoretical unpacking to generate insights into the socio-economic interactions between international staff and local populations beyond the material alone. Given Jordan's status as a relatively stable and safe country, its location amidst conflict settings such as Israel-Palestine, Iraq and Syria, and its high refugee population, many international and regional non-governmental organisations (NGOs), focusing on humanitarianism and development, base themselves in Amman. During the last two decades, the rate of humanitarian staff has globally risen sharply (Fast 2014, p.149). While exact numbers are not available, this trend is mirrored in Jordan, where interveners are working for UN agencies, in particular UNHCR and UNRWA, as well as international NGOs, such as the International Committee of the Red Cross and the Norwegian Refugee Council, and Jordanian NGOs that employ foreign staff. While international staff that relocate with families to Jordan often move to wealthier West Amman, younger singles and couples are more commonly living in areas such as Weibdeh and Jabal Amman.

This article focuses on a single case study, the neighbourhood of Weibdeh. Weibdeh provides a suitable site for exploring the effects of an intervention community less divided 
from the local community by spatial or economic boundaries. Located on a hill skirting Amman, Weibdeh was once a place for artists to retreat from the chaos of the capital. Over the last decade the increasing presence of international employees in the humanitarian sector has brought social and economic changes to the neighbourhood, as local residents adapt to the new opportunities and obstacles presented by the presence of the intervention community. The empirical part of the article rests on in-depth fieldwork conducted in June and July 2016, and initial observations from when the author was previously living in the neighbourhood in a professional capacity between December 2014 and July 2015. Data was collected through observations in the area, lived-experiences and interviews with a range of local and international residents. Overall, 14 in-depth interviews were conducted for this study, five with international and nine with local residents. All interviewed locals had either lived or worked in the neighbourhood for at least ten years and were of Arab origin. The time interveners had spent in Weibdeh varied from one month to six years, reflecting the transitory nature of their profession. We acknowledge that the researcher's positionality as a Western scholar may have impacted on local interviewees' willingness to critically interrogate local intervener relations if the researcher was perceived as part of the intervener social group and not an outsider to both communities. Yet this and the author's previously status as a member of the intervention community greatly facilitated participant observation in interveners' social circles. Much of this relates to issues recently discussed in articles using auto-ethnography in peace research (see eg Brigg and Bleiker 2010).

One of the main analytical challenges is the establishment of categories such as 'interveners' and 'locals'. The research project had to adopt looser, and somewhat contested, definitions of both labels. These categories are based on social perceptions rather than actual place of birth or profession. Although many Arabs of Jordanian, Palestinian, Saudi Arabian, and Syrian origin living in Amman cannot strictly be classified as local in the sense that they were born or have always lived in Amman, the article uses 'local' for all Arabs living in the neighbourhood, since interveners do not tend to distinguish between those from the region who are new to the area, and those native to Amman. Even for Arabs living in Jordan, the application of such a vague yet restrictive term as local is surely problematic, since many people who were born in Jordan but are of Palestinian origin would not define themselves as Jordanian, although they are certainly 'local'. Similarly, while only interveners - which we understand as foreigners working in the humanitarian or development sector - were interviewed for this study, local residents were not necessarily able to differentiate between 'interveners' and non-Arabs of a similar socio-economic class living in the neighbourhood, 
such as international students or business people. We thus followed a categorisation based on social perceptions that, in some cases, would contradict the self-identification of interviewees and residents. Despite these categories, the article does not try to set up a dichotomy between international and local actors with internationals as the power holders and locals as the recipients of interventions and change that is imposed upon them. On the contrary, we rather see this article as a contribution to debates around frictions and hybridity (Björkdahl and Höglund 2013, Peterson 2012, Mac Ginty 2011) with a particular interest in the dynamics that emerge as results of the encounters between different actors, their discourses and practices which, as Björkdahl and Höglund (2013, p.292) argue, produce new realities triggered by conflictual encounters reflecting needs and elements of all actors. While most authors focus on how local actors adapt or localise international ideas and practices, this article also points out how internationals internalise and engage with local practices, showing that this process is not monodirectional.

\section{Spatial economics and intervention gentrification}

As argued above, the presence of intervention communities does not lead to ,large scale change in the makeup of a national economy or even the entire urban area. However, we can sketch out at least three areas that tend to be impacted by the presence of large groups of interveners: i) architecture and landscape, ii) economy and employment possibilities, and iii) infrastructure in neighbourhoods where interveners are located. The results of intervention gentrification thus include the opening or closing of shops, building of roads, and additional housing, the inflation in property prices, and local business adapting their offerings to suit the demands of the intervention society, which usually means an increase in international products, restaurants and entertainment opportunities (see also Beber et al 2016). As outlined, the process of intervention gentrification transcends the material and involves a change in norms and social boundaries, as such it is also, and equally importantly, cultural and social. Intervention gentrification mirrors the spatial implications of neoliberalism more globally. Since space serves hegemony, capitalism is able to replicate spatial practices in order to monopolise everyday life, such as by reproducing private property and private enterprise (Lefebvre 1991, p.11). The value and scarcity of space forces workers out to the periphery, leaving the middle class and elites in the (urban) centre, where wealth and power is often concentrated, and thus groups are kept separate and out of contact (ibid, p.375).

In Amman neoliberalism is creating "emerging islands of excessive consumption for the elite" (Elsheshtawy 2011, p.46). Like most urban areas the city "shows marked socio- 
spatial polarisation between its wealthy neighbourhoods on the one hand and its poorer socioeconomic quarters on the other" (Potter et al. 2007, p.4) with a clear divide between the deprived East and the wealthier West of the city. Jabal al-Weibdeh is part of the district of $\mathrm{Al}$ Abdali and is more likely to house middle income households without being a rich or upperclass area. In line with the process of intervention gentrification, the types of businesses to open in Weibdeh are more upmarket and catering to the needs of higher incomes. A number of boutique shops have opened during the time of conducting research, among them a bakery, health food store, salon and leather goods shop. A fruit and vegetable shop infamous for being one of the most expensive in Amman is situated in the centre of the neighbourhood. Significantly, the majority of Weibdeh's local residents are homeowners, and are thus able to benefit from the excessive rent charged to foreigners and the additional capital influx without being in danger of being pushed out of the area themselves. Thus, our analysis is situated in a space already embedded in global dynamics of gentrification that moved a number of the area's residents into the richer middle class and dislocated poorer residents to other parts of the city.

At the same time, some residents see benefits from the international presence: a member of the Friends of Weibdeh Cultural Association ${ }^{8}$ believes the presence of foreigners is supporting the maintenance of the traditional and cultural atmosphere of the neighbourhood. While one might presume that the presence of intervention communities would encourage the opening of international chains in the area, Weibdeh's intervention economy ${ }^{9}$, in fact, counteracts the effects of 'McDonaldisation', and supports the majority of the community's wish to preserve the neighbourhood's 'traditional' appearance. ${ }^{10}$ Many of the smaller boutique shops and cafes preferred by local residents are also frequented by interveners, as are many of the neighbourhood's cultural events, walks around Weibdeh's galleries, and local music events that enjoy a mix of nationalities. ${ }^{11}$

\section{Wasta: The importance of social relations in Amman}

If we are looking at spatial economics of Weibdeh- which we understand as analysing the economic interactions occurring in a defined space - we already acknowledge the importance of the social component to this analysis, as all spaces produce their own social realities - in particular in situations of conflict (Björkdahl and Buckley-Zistel 2016, Vogel 2018). Foucault (1984, p.48) argues that 'space takes for us the form of relations among sites,' and thus becomes a social construct rather than a geographical location. Social networks and relations are typically seen as subordinate to economic transactions not the least because researchers 
often come from societies where social relations are seemingly less important or relevant to economic processes, and where the two concepts are less interconnected than in many Middle Eastern societies. This is reflected in liberal development theories that favour individualisation, and treat collectivism as inferior (Barnett et al. 2013, p.41). Further, neoclassical economics would consider social networks and relations as market distortions that contradict the basic assumptions of a perfect, symmetrical information structure and profit maximization opportunity for the individual (Kropf and Newbury-Smith 2016). However, with the focus on spatial economic dynamics, a social component needs to be taken into account more carefully. Many Arab societies use the term wasta to describe connections that are used to access economic or social opportunities at all levels of society (Al-Ramahi 2008, Eganand and Tabar 2016). More than simply enhancing the opportunities of certain individuals, it is rooted in the daily operations of societies, present in educational, governmental and legal institutions (Kropf and Newbury-Smith 2016). As a bottom-up mechanism, wasta can potentially be more inclusive than state institutions, and, where institutions are weak, it can be a mechanism for generating social order and resolving disputes (Berger et al. 2015). On the other hand, the idea of wasta includes clear mechanisms of exclusion. It is often compared to ideas of nepotism or favouritism but Barnett et al. (2016, pp.5-6) argue that while bribery and other forms of corruption are typically characterized by a quid pro quo, wasta does not require a direct exchange and is similar to an invisible hand that facilitates complex exchanges within a social network, and, we argue, between social networks. This also points to a long-term timeframe as any advantages may only occur in the future. While the concept usually is not spatially limited, its importance can become apparent if we are analysing a particular space.

To understand the interactions and transactions between local residents and interveners and how wasta plays a crucial role in these interactions, it is worth describing the two networks first, and why they can be seen to act as two separate networks with their own (imagined) resources. Locals and interveners are rarely walking through the neighbourhood together, and interveners mostly socialise with one another - either with work colleagues or with other interveners living in the neighbourhood. All of the interveners interviewed had mostly foreign friends, and the one who had been living there the longest still estimated that only $30 \%$ of her close social networks were local. Another noted that he would socialise with locals in different settings than those in which he would meet other interveners, pointing to existing spatial boundaries. A café employee highlighted the existence of temporal divisions, with foreigners more likely to come during the day, and local residents in the evening. At the 
same time, locals often collectively refer to interveners with the Arabic term 'ajanib' (foreigners) showing there are perceived as one collective group. ${ }^{12}$

While it is typically argued that closure of networks is needed to realise the value of wasta, it can also bridge structural holes between them (Burt 2001). A number of exchanges therefore take place that, while bridging spatial boundaries, also enable each community to use the other for different purposes. Together, these exchanges form Weibdeh's intervention economy and wasta - or the interconnectedness of the social and the economic - becomes a relevant lens through which we can better understand these interactions. The following sections will outline the different forms of economic ad social interactions and transactions between local residents and international residents in the area.

\section{Challenging social norms and gaining access to economic opportunities}

Similar to how intervener compounds become spaces of exceptional behaviour (Smirl 2015), the presence of an intervention community in Weibdeh has encouraged the creation of locations where experiences can be accessed and behaviour displayed that is not permitted, or at least disapproved of, elsewhere in Amman. This creates space for local youth to challenge the strict social norms of their community. Since many clubs turn away groups of Arab men, by befriending foreigners, especially women, local men are able to enter clubs and bars. At parties held by interveners, locals enjoy being part of a foreign crowd and sexual relations can also be easier amongst foreign women. ${ }^{13}$ This creates some tension in the local community: "They pretend that they are like your people, not our people" 14 was one local interviewee's take on Weibdeh's youth. Another criticised young Ammanis for copying the lifestyles of foreigners that they see in movies. ${ }^{15}$ This implies a fascination with American and Western European culture exhibited by youth in the Middle East (Fuller 2004, p.10). Connections to access this culture are increasingly preferred over the family arrangements that more traditionally fill free time in Middle Eastern societies (Tobin 2012, p.99). High unemployment rates, the deterioration of living conditions and frustration with the political elite, as well as the fabricated representations of American society in Hollywood films, ${ }^{16}$ increases the idolisation of such lifestyles (Fuller 2004, pp.10-11). However, this often happen in secret, as some local youth go to parties and bars without the consent of their families. $^{17}$

Other opportunities sought by locals had a significant economic element to them. In the same way that locals may interact with UN missions with employment objectives in mind (Pouligny 2006, p.189), interveners' professional networks are of potential value, especially 
since they are made up of NGOs or governmental organisations whose policies may directly affect them. Indeed, the author, when working for one agency, was asked by a friend if she could help him find a job in the organisation's IT department. Furthermore, interveners are seen as having international connections beyond Amman. They are regularly asked by local friends how to get visas and employment abroad, or if it is possible for internationals to issue invitations to support visa processes. ${ }^{18}$ Such networks thus become potentially usable in the short or long-term.

\section{Social prestige}

The middle class is typically defined by economic institutions with regards to levels of income or consumption (Kharas and Gertz 2010, p.3), as can be seen by the World Bank's approach to linking the middle class to income and GDP growth. The middle class in Amman relates better to Taylor's (2002, p.106) notion of a social imaginary, whereby "people imagine their social existence, how they fit together with others, how things go on between them and their fellows...". Rather than markers of wealth, what enable those, who range from students with little income to government and service-sector employees, to identify as middle class are their shared social and cultural practices, with many articulating a "suburban consciousness", which typically orients itself around 'Western' cultural references, and a desire to distinguish themselves from the lower classes (Tobin 2012, Watenpaugh 2006) by situating themselves in a discourse of modernity.

Therefore, though those who constitute the middle class in Weibdeh include landlords and business owners who have certain levels of wealth, members are also distinguishable by their social assets. Education, especially attending university, an ability to speak English, and a more liberal outlook than the conservative lower classes, facilitate access into the middle class. ${ }^{19}$ Individuals who would typically be seen as working class based on their income are able to feel a part of this community by virtue of being part of the neighbourhood's networks. For instance, one taxi driver who found it difficult to cope with the increasing living costs in the area, proudly spoke of his foreign education and ability to speak a number of European languages, and of his son who was a successful musician.

\section{Language}

Even if international networks do not directly translate into employment opportunities, they provide the chance to gain other skills that might translate into opportunities. One particularly valuable resource exchanged between both groups is language. There is a presumption that 
people in Weibdeh can speak English, with many of the cafés whose custom is mainly Arab, only having their menu in English. Some employ foreign waiters who speak English but no Arabic. Half of the locals interviewed showed pride in their ability to speak English, in addition to many other languages, and one named it as the most important aspect of having friends from the intervention community. ${ }^{20}$ As a global language and the language of consumerism, English is increasingly useful for gaining employment (al Hassan 2008, p.2).

This importance of language skills holds true for international residents too. In Jordan, Arabic becomes a particularly useful skill for foreigners in pursuit of employment and is often an asset when applying to NGOs working in the region. Not knowing the language also decreased interveners' quality of life and ability to interact when leaving the neighbourhood. Non-Arabic speakers are, for instance, more likely to be exploited by taxi drivers, who are known for taking foreigners on longer routes in order to charge them higher rates. One intervener noted how she felt "helpless" in such situations because she could not speak Arabic. ${ }^{21}$ Basic language learning was thus described as one of the benefits of interacting with the other community, particularly as it enabled them to practice the spoken form of Arabic.

"The people I speak to for the most part are my neighbours, and that's also the most Arabic interactions I have... because they speak some English sometimes but not really at all... so I kind of force to try and talk Arabic with them. "22

The wife of a landlord whose house is rented to foreign tenants frequently meets with their tenants to help them with their Arabic. ${ }^{23}$ Thus, tenants are offered an additional incentive to stay in this accommodation.

When both locals and interveners wish to exchange language skills, the usual social rituals are bypassed and others are sought solely as 'language partners'. Language partners typically meet in cafés that act as a neutral space between the two networks' private spaces. In the author's experience, when the purpose of the interaction is clear, the social exchange often does not extend beyond this. Such practices highlight the economic component of social networks and interactions, with the giving of a title to those who form a function in social transactions.

\section{Transforming interactions into economic gains}

It is on the basis of these social interactions that most economic transactions between foreigners and locals in the neighbourhood are formed. As observed in other intervention societies (Pouligny 2006; Aning and Edu-Afful 2013, 2015; Jennings 2015), interveners' 
economic capital greatly affects Weibdeh's local society. Between 2009 and 2016, over thirty new food and beverage outlets opened in the neighbourhood (Smith 2016), coinciding with the growth of the foreign staff. One landlord estimated that $85 \%$ of money in Weibdeh is from foreigners, through the renting of properties and money spent on consumption goods. "If the foreigners leave," he insisted, "Weibdeh will crash". ${ }^{24}$ A local shop owner confirmed that "foreigners keep Weibdeh running" 25 and that rent prices would drop and employment opportunities decrease in the neighbourhood if the international community were to leave. Local residents thus try to prevent this by building economic exchanges on connections with the intervention community that have been nurtured over time by the neighbourhood's local population to encourage an influx of economic capital. A property owner who primarily rents to foreigners stated:

\begin{abstract}
"Why do foreigners like [it] here and not like Abdoun or Rabiya or Sweifieh? There the people aren't used to the foreigners, they think that any foreigner is [clicks fingers] easy... This doesn't happen in Jabal el Weibdeh. In Abdoun it happens, because they don't have experience, in their mind they don't understand the foreigners. But the residents of Jabal el Weibdeh love the foreigners, and not just love... 'ushuq' - the end of love..." ${ }^{26}$
\end{abstract}

This is reflected in the terms interviewees commonly used to describe international residents such as 'friends' and 'family', and all stressed that they found foreigners respectful and that problems rarely occurred between them. ${ }^{27}$ Although landlords and business owners described foreigners as 'friends', few actually socialised with them outside the business context, and their contact was limited to their own tenants or customers, indicating that the line between transactions and relationships is therefore often blurred. Similarly, interveners did attest to the friendly atmosphere of the neighbourhood. While they tended to speak about locals outside of Weibdeh collectively, those within Weibdeh were spoken of as individuals, such as references to a particular acquaintance or shop owner, suggesting that the forging of networks with locals in Weibdeh helped break down interveners' perception of them as the 'other'. Nonetheless, it is evident that these relations are not simply a matter of friendships but strategic on many levels and that the local community favours a certain type of international resident. Another landlord recognised that the interveners who come to Weibdeh are likely to be more educated, and therefore better connected: "all of them who come have certificates, are selected, they don't come from the fish market". ${ }^{28}$ The view of many locals that interveners have 'good morals ${ }^{\prime 29}$ when it comes to paying rent on time and looking after the property, is also significant, given that in communal societies there exists a greater 
collective responsibility to take care of one another (Oosterlynck et al. 2017, p.4). Morality therefore suggests a trustworthiness that is important for nurturing social relations.

Giving positive accounts of local-intervener relationships is in the interest of the majority of local residents who benefit directly or indirectly from the intervention community. It ties in with the economic rationale of keeping the international community in their area: local residents essentially advertise the neighbourhood and try to establish a welcoming atmosphere to attract future members of the intervention community and prevent Weibdeh's carefully constructed economy from collapsing. These benefits are not one-sided: while the preceding section outlined the potential gains of the local community from interactions with the intervention community, the next section focuses on the benefits to the intervention community.

\section{Interveners' economic benefits: Access to local knowledge}

In Jordan, few prices are fixed and many depend on an ability to negotiate and knowledge of prices in the area. For the intervention community, local connections are important for overcoming the lack of knowledge on the value of goods and services. Landlords, especially, try to benefit from new interveners' lack of knowledge of local pricing which makes them vulnerable to exploitation. While fruit and vegetable sellers may earn a few extra dinar from interveners, landlords can double the rent they charge. Exacerbated by their lack of Arabic language skills, the majority of interveners struggle to find suitably priced accommodation due to lack of local contacts and information prior to their arrival in Amman. They either rely on their employer to find and subsidise accommodation, which enables landlords to charge particularly high rent, or find housing through online sites such as expatriates.com or the 'Amman Expats' Facebook group, which specifically target internationals without contacts in the country to advertise properties well above market value. On finding out the price a family member was charging foreigners, one interviewee exclaimed: "My uncle is a thief!". ${ }^{30}$ Here, wasta - or connection with local residents- can help to mitigate the effect and the information asymmetries of the property market. This expands into different areas of the daily economic interactions: a shop owner stated that he had no close friendships with foreigners but offered his customers "help and connections", such as finding reliable taxi drivers and information on the city. ${ }^{31}$

Those interveners who had lived in the area the longest appeared indifferent to making local friends. Rather, they valued locals for the help they could offer. ${ }^{32}$ Indeed, the intervener 
and her husband (also an intervener) who had been in the neighbourhood the longest out of those interviewed had developed relationships with locals exclusively for such means.

"I cannot really say 'friends' but whenever I need something I have points of reference in the area. So, if I need, for example... a taxi driver... [my husband] took a couple of afternoons to go around to some of the shopkeepers... and he was asking for advice..." ${ }^{33}$

This displays a shift, over time, in the way interveners viewed social connections. While interveners newer to Jordan were most concerned with forging friendships with locals, those who had spent more time in the country had become comfortable with the idea of using connections strategically.

\section{Liberal lifestyle, security and a sense of home}

As discussed, local residents seek to create a positive impression of the neighbourhood. This is not limited to its friendly reputation. Many of the interveners interviewed suffer from a lack of belonging and are thus attracted to Weibdeh, in part, because it allows them to act and dress outside the societal norms that are applied in other parts of the city. The neighbourhood also makes concessions on other habits members of the intervention community are used to. This includes drinking - even during Ramadan - and organising private parties throughout the year. Local residents are used to these activities and believe they are a "freedom" of interveners. Residents critical of these activities nevertheless tolerate them. During an interview, an older man commented on two foreigners walking past, holding hands, as being inappropriate. He then criticised public displays of affection, such as kissing, for being disrespectful, yet still had an overall positive view of the intervention community and made no direct indication to the bypassers that he detested their behaviour. ${ }^{34}$

This ties in with local attempts to maintain interveners' trust in the safety of the neighbourhood. Local residents stressed that anyone who gave foreigners problems were "from outside", and locals worked together as a community to solve security issues that arose. When an intervener's apartment was burgled, local residents quickly found the person responsible and returned the stolen goods. In particular, women enjoy the liberal atmosphere, as they do not have to follow a strict dress code and are less likely to be stared at. ${ }^{35}$ Female interviewees felt confident to walk alone through the neighbourhood but some attested to being warier of doing so in other areas of town for fear of sexual harassment, and asked local male friends to accompany them downtown as a form of protection. ${ }^{36}$ That does not mean that social etiquettes are entirely removed from interactions in Weibdeh, particular when it 
comes to gender roles. Female interveners felt the pressure of behaving in an appropriate way and one refrained from handshaking after feeling that she had once caused offense by shaking hands with a man. Another was wary of making people feel uncomfortable or exposing herself to "risky situations" but accepted such boundaries as "a structural part of relationships here". These gender differences extend to the relationships that can be formed more generally, with most shop assistants, taxi drivers and landlords usually being male. While local men frequent interveners' parties, local women are rarely present, and interveners believe it is difficult to make friends with young local women.

The sense of home extends to the spaces and products that are on offer in Weibdeh. Within the year of conducting research in the area, a number of cafes had been expanded, or changed to appear lighter and roomier - a style observed by one local resident to be that preferred by foreigners, ${ }^{37}$ and, in Weibdeh, three bars existed that openly served alcohol. A number of boutique and organic stores sold products clearly catering to international residents of the area. A bakery sold a range of global products, including Italian, Austrian and English items, and labels were written in English. The most frequented supermarket in the neighbourhood stocked a variety of international products. ${ }^{38}$ Thus, local residents enable interveners' freedoms and cater to their consumption preferences in order to attract them to the neighbourhood, while interveners respect the limits of locals' tolerance.

\section{The intervention society's economic, social and cultural impacts on Weibdeh}

Despite being situated in an upper middle-income country, Amman is still deeply affected by the international humanitarian presence and the acceleration of gentrification in Weibdeh is a direct result of it. The process is not subtle but recognised by local residents as the greatest impact of the international presence. Clearly, as focused in Weibdeh as this intervention economy is, the economic benefits are unequally distributed, with landlords and businesses in the neighbourhood gaining at the expense of previous residents and businesses in other parts of the city. However, examining the socio-economic transactions taking place in Weibdeh also paints a picture of a dynamic and complex intervention society that extends beyond primarily economic transactions but often connects back to them. Given the prominence of wasta in countries such as Jordan, the interdependency of the social and the economic is not surprising, yet it is often overlooked in research conducted through a Western lens that separates social and economic spheres. This challenges some of the key assumptions in the hybridity debate that observes a hybridisation of "liberal (international) and non-liberal (local) institutions, practices and values" (Nadarajah and Rampton 2015; also: Mac Ginty, 
2011) when internationals and locals interact. Instead, the transactional but mutually beneficial nature of wasta allows both communities to retain their way of life while tolerating the other's needs; implicitly assuming that this will facilitate economic or socio-economic progress or comfort for both communities. This requires some form of civility and tolerance from both sides: despite the greater freedoms interveners experience in Weibdeh in contrast to other parts of the city, as locals work to control the rules of the neighbourhood, they have to adapt their behaviour too. For instance, none of the interveners interviewed drank, ate or smoked outside during the day in Ramadan. In fact, a local resident claimed that foreigners are more respectful of such customs than some locals. Such unspoken 'rules' are maintained through social relations acting as regulatory norms to those within a network - a system of 'informal contract reinforcement' (Putnam 2001, p. 7) or what one local resident referred to as unwritten "community standards" and "local community rules". Since trust is an important factor for gaining access to social networks and making full use of wasta, both groups make concessions. Rather than inevitably fractured and conflicting, the social structure is thereby composed of levels of negotiations and discourse (Lin 2001, p.6) that allow several communities and norms to exist in parallel.

Further, while a focus on economic transactions typically situates locals as victims of intervention economies with little to gain but an income just above the poverty line, we have shown that local residents find multiple ways to make use of the presence of humanitarians and aid workers - economically and socially, and vice versa. Of course, these possibilities are not independent of unequal power structures. Residents work within them and reproduce them. Due to the nature of Weibdeh as an enclave, economic and socio-economic possibilities are largely limited to the already more affluent residents of the neighbourhood. Youth therefore gain advantages that enable them to excel above their peers, while members of Weibdeh's cultural associations hold onto their vision of Weibdeh, at the expense of those from outside who may wish for the continuation a modernisation of the entire city that have taken place in other neighbourhoods already.

Conceptually, we can differentiate between the effects of international and local residents sharing spaces in intervention societies, as well as the processes of economic interactions that are stipulated by it. The findings point to five main categories: monetary and non-monetary opportunities, socio-economic changes, social changes and changes in infrastructure. We do not suggest that we can neatly divide effects and processes into separate categories, but many of them mutually constitute each other. The processes described lead to 
intervention gentrification, and the fact that rules for acceptable behaviour, lifestyle and infrastructure in the neighbourhood change, attracts more internationals. It is thus better to think of this process as circular rather than as a strict matter of cause and effect.

Most importantly, the findings show that there are both monetary and non-monetary opportunities and exchanges within the intervention society. Some residents gain language skills - English or Arabic - that can improve their social status and potentially be transferred to economic capital as it advances employment opportunities. The higher income brought to the neighbourhood by interveners can be utilised to keep shops, artists, and cultural centres afloat which, again, causes and at the same time is a cause of intervention gentrification. Further, many of these economic interactions directly impact on social norms: youth use the opportunity to gain connections and knowledge that may be of future benefit, but also to subvert the restrictive lifestyle imposed on them by a traditional society. This is exemplary of the tactics that Michel de Certeau (1984) describes as those practices used to subvert 'strategies' - the rules of being, and unequal forces, that are produced and imposed by space. Such methods are comprised of everyday practices, namely interactions with others, such as walking, speaking and consuming, that bring people into contact with each other (ibid, pp. xixii). Local residents living alongside intervention communities are thus not passive recipients but actively shape and contribute to the formation of everyday economies in the intervention society. Given widespread insecurity, conflict and the migration crisis in the Middle East, and Amman's stability, the current situation suggests a long-term presence of humanitarian and peacebuilding organisations in the city, and that such trends are set to continue. The examination of socio-economic transactions draws attention to the everyday lives taking

place below the gaze of international actors. The same interveners that come to play a role in Weibdeh's socio-economic transactions could benefit from taking such experiences away from the everyday and into their professional lives.

\section{Conclusion - The implications for post-conflict and intervention economies}

The local turn in peace and conflict studies and international relations, as well as the more recent spatial turn, have so far engaged insufficiently with the impact of interventions on the formation of local economies and the infrastructure of neighbourhoods both during and beyond the intervention phase. Examining Weibdeh's intervention economy shows how the spatial, material and social are interlinked in situations of international interventions, and how these interactions create new economies. Despite the general hope that interventions 
bring prosperity and economic growth to conflict-affected countries, this article drew out some of the unintended economic and socio-economic consequences that often replicate wellknown patterns of capitalism. The majority of local-international interactions seem to benefit the wealthy, such as (often international) landlords and business people who let properties at higher rates to international staff and engage in trade where profit margins are usually higher than in transactions with domestic populations (see Pouligny 2006, Jennings 2015, Beber et al 2016). As such, the hierarchies of inclusion and exclusion present in such economic interactions are in danger of reinforcing some of the root causes of conflict, and thus increase the likelihood of future instability in host societies in their post-conflict economies. There is a need to further investigate the nature of intervention gentrification in relation to wider processes of neoliberal restructuring implicit in peacebuilding and how this affects host communities. The housing of international employees is one of the most prominent examples from various case studies underlining the point that a process of intervention gentrification is likely to occur in societies that experience a large influx of international aid workers which means that some local residents - often with less economic capital - are pushed out of popular and prospering areas. Intervention gentrification also creates parallel economies to meet needs of international workers that distort labour, rental and retail markets and the emergence of a temporary service industry (Carnahan et al, 2006, p.9).

However, this is not where processes of economy formation end, it is rather where our analysis started. The new space shapes economic interactions, but economic interactions also shape the space they are occurring in, including social interactions and norms. While the processes of neo-liberalism and capitalism undoubtedly bring negative effects such as deepening inequalities where no social and welfare policies are in place to mitigate them, many actors try to take advantage of the new realities and, as we have shown in the case of Amman, the interactions can benefit both groups. The space is now occupied by interveners and locals with shared class-characteristics rather than cutting across them. However, the economic and social risks of intervention societies are unequally distributed and the situation is complicated by the temporality of the international presence. Daxner et al. (2010) point out the temporal nature of intervention societies, making clear that the international presence in any given country is thought of as a state of exception that, in the best case, is no longer required after peacebuilding or humanitarian objectives are met. This emphasises contradiction between the long-term nature of wasta and the short-term nature of international interventions. While aid workers stay for a number of years or months, the neighbourhoods their presence transforms are long-term homes to local residents, and the 
intervention community is deeply interwoven in their economic livelihoods and the social make-up of the space. Thus, those who have invested their lives in the neighbourhood are at risk of losing out to those whose presence is only transitory, if the area cannot continue to attract an international interest. Individuals will hardly feel a responsibility towards the social and economic structures their presence has created. Given the potential negative effects of their presence, aid organisations would be well-advised to avoid exacerbating potential impacts of socio-economic divisions when, for example, deciding on price caps for rent and providing better orientation to international employees. Currently, the international community has no mechanisms in place to mitigate these effects when leaving - possibly creating social conflict or at least economic precarity for those staying in the communities. It would therefore be advisable for the economic effects of the intervention society and intervention gentrification to be considered in more far-reaching economic and social studies. Further research will also have to find answers on how gentrified quarters interact with other parts of the city and shape violence, insecurity and inequality within urban areas and connecting regions. 


\section{List of References}

Al Rabady, R. and Abu-Khafajah, S. 2015. 'Send in the clown': Re-inventing Jordan's downtowns in space and time, case of Amman. Urban Design International, 20(1), 1-11.

Al-Ramahi, A. 2008. Wasta in Jordan: A distinct feature of (and benefit for) Middle Eastern society. Arab Law Quarterly, 22(1), 35-62.

Aning, K. and Edu-Afful, F. 2015. Peacekeeping Economies in a Sub-Regional Context: The Paradigmatic Cases of Liberia, Sierra Leone and Côte d'Ivoire. Journal of Intervention and Statebuilding, 9(3), 391-407.

Autesserre, S. 2014. Peaceland: conflict resolution and the everyday politics of international intervention. Cambridge: Cambridge University Press.

Barnett, A., Yandle, B. and Naufal, G. 2013. Regulation, trust, and cronyism in Middle Eastern societies: The simple economics of "wasta". The Journal of Socio-Economics, 44, 41-46.

Beber, B., Gilligan, M., Guardado, J. and Karim, S. 2016. Challenges and Pitfalls of Peacekeeping Economies

https://www.nyu.edu/projects/beber/files/Beber_Gilligan_Guardado_Karim_PK_Economy.p df (last accessed 15/5/17)

Berger, R., Silbiger, A., Herstein, R. and Barnes, B.R. 2015. Analyzing business-to-business relationships in an Arab context. Journal of World Business, 50(3), 454-464.

Björkdahl, A. and Buckley-Zistel, S. 2016. Spatializing Peace and Conflict. London: Palgrave.

Björkdahl, A. and Höglund, K. 2013. Precarious peacebuilding: Friction in global-local encounters. Peacebuilding, 1(3), 289-299.

Brigg, M. and Bleiker, R. 2010 "Autoethnographic International Relations: Exploring the Self as a Source of Knowledge.” Review of International Studies 36 (3), 779-798.

Burt, R.S., 2001. Structural Holes versus Network Closure as Social Capital. in Lin, N., Cook, K.S. and Burt, R.S. eds., Social capital: Theory and research. Transaction Publishers.

Carnahan, M., Durch, W. and Scott, G. 2006. Economic Impact of Peacekeeping, available from http://m.buildingmarkets.org/sites/default/files/economic impact of un peacekeeping marc h_2006.pdf, last accessed 25.02.2018.

Chandrasekaran, R. 2006. Imperial Life in the Emerald City. Inside Iraq's Green Zone. Alfred A. Knopf: New York

Caruso, R, Prabin Khadka, Ilaria Petrarca \& Roberto Ricciuti (2017) The economic impact of peacekeeping. Evidence from South Sudan, Defence and Peace Economics, 28:2, 250-270

Daxner, M, Jan H. Free, Thorsten Bonacker, and Christoph Zürcher. 2010. 'Einleitung.' In Interventionskultur. Zur Soziologie von Interventionsgesellschaften, 
ed. Thorsten Bonacker, Michael Daxner, Jan H. Free, and Christoph Zürcher, 7-

18. Wiesbaden: VS Verlag.

De Certeau, M. 1984. The practice of everyday life. Trans. Steven Rendall. Berkeley: University of California Press.

Egan, M. and Tabar, P. 2016. Bourdieu in Beirut: Wasta, the State and Social Reproduction in Lebanon, Middle East Critique, 25(3), 249-270.

Elsheshtawy, Y. 2008. The evolving Arab city: tradition, modernity and urban development. London: Routledge.

Ernst, B., Sooreea, R., Gokcek, G., and Spain, D. 2014. The economic impacts of United Nations peacekeeping operations: growth versus level effects. International Journal of Public Policy, 10(1-3), 100-117.

Eyben, R. 2011. The sociality of international aid and policy convergence. Adventures in Aidland: The Anthropology of Professionals in International Development. Berghahn, New York, 139161.

Fast, L. 2014. Aid in Danger - The perils and promise of humanitarianism. Pennsylvania: Pennsylvania University Press.

Foucault M. 1984. Of other spaces, Heterotopias. Architecture, Movement, Continuite, 5: 46-49.

Fuller, G.E. 2004. The youth crisis in Middle Eastern society. Brief Paper. Clinton Township: Institute of Social Policy and Understanding.

Goetze, C. and De Guevara, B. 2012. The 'statebuilding habitus': UN staff and the cultural dimension of liberal intervention in Kosovo. London: Routledge.

Jennings, K.M. 2015. Life in a 'Peace-kept' City: Encounters with the Peacekeeping Economy. Journal of Intervention and Statebuilding, 9(3), 296-315.

Jennings, K.M. and Bøås, M. 2015. Transactions and Interactions: Everyday Life in the Peacekeeping Economy. Journal of Intervention and Statebuilding, 9(3), 281-295.

Kharas, H. 2010. The emerging middle class in developing countries.

(http://siteresources.worldbank.org/EXTABCDE/Resources/74556761292528456380/7626791-1303141641402/7878676-1306699356046/Parallel-Sesssion-6Homi-Kharas.pdf, last cited 4/4/17)

Kharas, H. and Gertz, G. 2010. The new global middle class: A cross-over from West to East. Wolfensohn Center for Development at Brookings,1-14.

Kropf, A. and Newbury-Smith, T.C. 2016. Wasta as a Form of Social Capital? An Institutional Perspective. In The political economy of Wasta: Use and abuse of social capital networking (pp. 3-21). Springer International Publishing. 
Lefebvre, H. 1991. The production of space (Vol. 142). Blackwell: Oxford.

Lin, N., 2001. Building a Network Theory of Social Capital in Lin, N., Cook, K.S. and Burt, R.S. eds. Social capital: Theory and research. Transaction Publishers, pp. 2-29

Mac Ginty, R., 2011. International peacebuilding and local resistance: Hybrid forms of peace. Springer.

Mvukiyehe, E. 2018. Peacekeeping and development in fragile states : micro-level evidence from Liberia. Policy Research working paper. WPS 8389; Washington, DC: World Bank Group.

Nadarajah, S. and Rampton, D. 2015. 'The limits of hybridity and the crisis of liberal peace', Review of International Studies 41(1), 49 - 72

Oldenburg, S. 2015. The Politics of Love and Intimacy in Goma, Eastern DR Congo: Perspectives on the Market of Intervention as Contact Zone. Journal of Intervention and Statebuilding, 9(3), 316-333.

Oosterlynck, S., Schuermans, N. and Loopmans, M. 2017. Place, Diversity and Solidarity. London: Routledge.

Peterson, J.H., 2012. A conceptual unpacking of hybridity: Accounting for notions of power, politics and progress in analyses of aid-driven interfaces. Journal of Peacebuilding \& Development, 7(2), 9-22.

Potter, R.B., Darmame, K., Barham, N., Nortcliff, S. and Mannion, A.M. 2007. An introduction to the urban geography of Amman, Jordan. Reading Geographical Papers, 182,1-29.

Pouligny, B., 2006. Peace operations seen from below. UN missions and local people. London: Hurst and Co.

Pouligny, B. 2009. Supporting local ownership in humanitarian action. Global Public Policy Institute-Humanitarian Policy Paper Series.

Putnam, R. 2001. Social capital: Measurement and consequences. Canadian Journal of Policy Research, 2(1), 41-51.

Rolandsen, Ø.H., 2015. Small and Far Between: Peacekeeping Economies in South Sudan. Journal of Intervention and Statebuilding, 9(3), 353-371.

Smirl, L. 2015. Spaces of aid: how cars, compounds and hotels shape humanitarianism. London: Zed

Smith, J., 2016. How entrepreneurs transformed this Amman neighbourhood, Wamda online http://www.wamda.com/2016/03/how-entrepreneurs-transformed-this-amman-neighborhood (last accessed 16/8/16)

Taylor, C. 2002. Modern social imaginaries. Public culture, 14(1), 91-124. 
Tobin, S.A., 2012. Jordan's Arab Spring: The Middle Class and Anti-Revolution. Middle East

Policy, 19(1), 96-109.

Verma, R. 2011. Intercultural Encounters, Colonial Continuities, and Contemporary Disconnects in Rural Aid: An Ethnography of Development Practitioners in Madagascar. Inside the Everyday Lives of Development Workers: The Challenges and Futures of Aidland, pp. 59-82.

Vogel, B. 2018. 'Understanding the impact of geographies and spaces on the possibilities of peace activism', Cooperation and Conflict, online first.

Watenpaugh, K.D. 2006. Being Modern in the Middle East: Revolution, Nationalism, Colonialism, and the Arab Middle Class. Princeton: Princeton University Press.

Yarrow, T. 2011. 'Maintaining independence: the moral ambiguities of personal relations amongst Ghanaian Development Workers', in Fechter, A.M. and Hindman, H. eds., Inside the everyday lives of development workers: The challenges and futures of Aidland. Sterling, VA: Kumarian Press.

\footnotetext{
' While economic institutions, such as the World Bank, typically link class to income, we recognise being 'middle class' in Amman as a social, not only economic, identity.

${ }^{2}$ We agree that the distinction between internationals/interveners and locals creates a problematic binary that is not always useful as an analytical category. However, we apply such categories in this article to describe a general pattern of behaviour and interactions; see discussion in the methodology section.

${ }^{3}$ Daxner et al (2010) use the term 'intervention societies' to describe the social outcome of international and local actors, positions and beliefs integrating.

${ }^{4}$ It is generally assumed that an international and particular peacekeeping presence in a region fosters investment through the provision of security and thus local and international willingness to make economic investments, see for example Caruso 2017.

${ }^{5}$ Peacekeeping missions differ from other humanitarian interventions in that employees are typically housed in compounds or barracks unlike humanitarian and aid staff who are more likely to integrate with host communities.

${ }^{6}$ This article deliberately avoids the term 'social capital' due to its contradictory and politicized nature and its recent use as a policy buzzword. Further, social capital has mostly been attributed to and studied in the context of Western and individualist societies and comes with the somewhat problematic assumption it would work similarly over space and time.

${ }^{7}$ For the 2017 financial year, the World Bank defines upper middle-income economies as those with a GNI per capita between $\$ 4,036$ and $\$ 12,475$.

${ }^{8}$ Interview local resident A (male), Amman, 27 June 2016.

${ }^{9}$ This term builds on the 'peacekeeping economy' that refers to the "everyday social and economic interactions between peacekeepers, a mission, and local people and communities" (Aning \& EduAfful 2015:391) and has been used to refer to those exchanges involving humanitarian and development workers and peacebuilders (Jennings \& Boas 2015). However, the term intervention economy refers more clearly to those social and economic interactions that occur between the local population and all types of interveners.

${ }^{10}$ At the same time, some criticise the development of areas in an 'oriental' style. This ties in with debates around 'oriental urbanism' that describe the process of regenerating areas of the MENA region in a style that was framed during colonial times. It is being argued that oriental urbanism is partly responsible for the paradoxical development now occurring in parts of Amman (see Al Rabady and Abu-Khafajah 2015).
} 
${ }^{11}$ Fieldnotes, Amman, 27 June to 03 July 2016.

${ }^{12}$ Ibid and interviews with intervener A (female), Amman, 02 July 2016 and intervener B (male), Amman, 08 July 2016.

${ }^{13}$ Fieldnotes, Amman, 27 June to 10 July 2016.

${ }^{14}$ Interview with local resident B (male), Amman, 27 June 2016.

${ }^{15}$ Interviews with local resident A (male), Amman, 27 June 2016 and local resident C (male), Amman, 27 June 2016.

${ }^{16}$ Interview with local resident B (male), Amman, 27 June 2016.

${ }^{17}$ Interview with local residents D \& E (male), Amman, 3 July 2016.

${ }^{18}$ Fieldnotes, Amman, 27 June to 10 July 2016.

${ }^{19}$ Ibid.

${ }^{20}$ Ibid; interviews with local residents A, B, D \& E (male), Amman, 26 June to 03 July 2016.

${ }^{21}$ Interview with intervener C (female), Amman, 27 June 2016.

${ }^{22}$ Interview with intervener D (male), Amman, 03 July 2016.

${ }^{23}$ Interview with local resident F (female), Amman, 03 July 2016.

${ }^{24}$ Interview with local resident C (male), Amman, 26 July 2016.

${ }^{25}$ Interview with local resident G (male), Amman 26 June 2016.

${ }^{26}$ Interview with local resident C (male), Amman, 26 June 2016.

${ }^{27}$ Fieldnotes, Amman, 27 June to 10 July 2016.

${ }^{28}$ Interview with local resident C (male), Amman, 26 July 2016.

${ }^{29}$ Interview with local residents C, D \& E (male), Amman 26 June to 03 July 2016.

${ }^{30}$ Interview with local resident B (male), Amman, 27 June 2016.

${ }^{31}$ Interview with local resident A (male), Amman, 27 June 2016.

${ }^{32}$ Interviews with interveners A \& C (female), Amman, 27 June to 02 July 2016.

${ }^{33}$ Interview with intervener A (female), Amman, 02 July 2016.

${ }^{34}$ Interview with local resident G (male), Amman 26 June 2016.

${ }^{35}$ Interviews with local residents A, B, C (male) \& H (female) and interveners A, C \& E (female), Amman 26 June to 10 July 2016.

${ }^{36}$ Interviews with local residents D \& E (male) and intervener E (female), Amman, 01-03 July 2016.

${ }^{37}$ Fieldnotes, Amman, 27 June to 10 July 2016 and interview with local resident B (male), Amman, 27 June 2016.

${ }^{38}$ Fieldnotes, Amman, 27 June to 10 July 2016. 